\title{
PYROXENE GEOTHERMS REVISITED - AN EMPIRICAL APPROACH BASED ON CANADIAN XENOLITHS
}

\author{
Herman Grütter ${ }^{1}$ and Rory Moore ${ }^{1}$ \\ ${ }^{1}$ Mineral Services Canada, Vancouver, Canada
}

\section{INTRODUCTION}

Pioneering experimental investigations in simplified model peridotite compositions (Boyd and England, 1964; MacGregor, 1974) spawned the use of pyroxene compositions to constrain mantle pressures and temperatures, and hence geotherms (Boyd, 1973). Thermobarometric expansion of the simple-system pyroxene-garnet relations to deal with complex naturally-occurring compositions has involved substantial further experimental investigation (e.g. Nickel, 1989; Brey et al., 1990; Taylor, 1998) and semi-empirical thermodynamic analysis (e.g. Mercier, 1980; Brey and Köhler, 1990; Taylor, 1998) that has been presented as reasonably successful by some authors (e.g. Finnerty and Boyd, 1987; Smith, 1999), or problematic by others (e.g. Carswell, 1991). Nimis and Taylor (2000) recently calibrated a semi-empirical thermobarometer for $\mathrm{Cr}$-diopside coexisting with garnet that appears to satisfy extant experimental and phasecompatibility constraints to within acceptable error for a wide variety of peridotitic bulk compositions over a broad P-T range. This new calibration presents an opportunity to empirically compare and contrast clinopyroxene-garnet thermobarometric results with those of orthopyroxene-garnet, for coexisting mineral pairs occurring in the same xenoliths. This abstract documents the initial results of such an investigation for kimberlite-borne peridotite xenoliths from Canadian localities. The results are also briefly compared with thermobarometric results for the Gibeon, Kimberley and North Lesotho kimberlite provinces in Southern Africa.

\section{DATA SOURCES AND METHODS}

The compositions of olivine (Ol), orthopyroxene (Opx), clinopyroxene (Cpx), garnet (Grt) and spinel ( $\mathrm{Spl}$ ) were captured from published literature sources and a limited number of unpublished theses (Appendix 1). All analyses were double-checked and clarification sought from authors were suspicious entries were detected. Pressure-temperature (P-T) conditions were calculated using core and rim compositions with a customised version of PTEXL (Köhler, pers. comm., 1993). We iterated the Cr-diopside thermobarometer of Nimis and Taylor (2000) to obtain initial P and T values (denoted PNT00 and TNT00 respectively). Iteration of other thermobarometer combinations showed that TNT00 values correlate well with temperatures calculated using alternate Cpx-solvus thermometers (e.g. TBKN of Brey et al., 1990, see Fig. 1). TNT00 values were therefore fixed and carried forward during calculation of Opx-Grt pressures with the PBKN, PNG85 and PMC74 barometers (Brey et al., 1990; Nickel and Green, 1985; Finnerty and Boyd, 1987). This procedure ensures that differences between Opx-Grt and Cpx-Grt barometry results are not correlated with temperature differences.

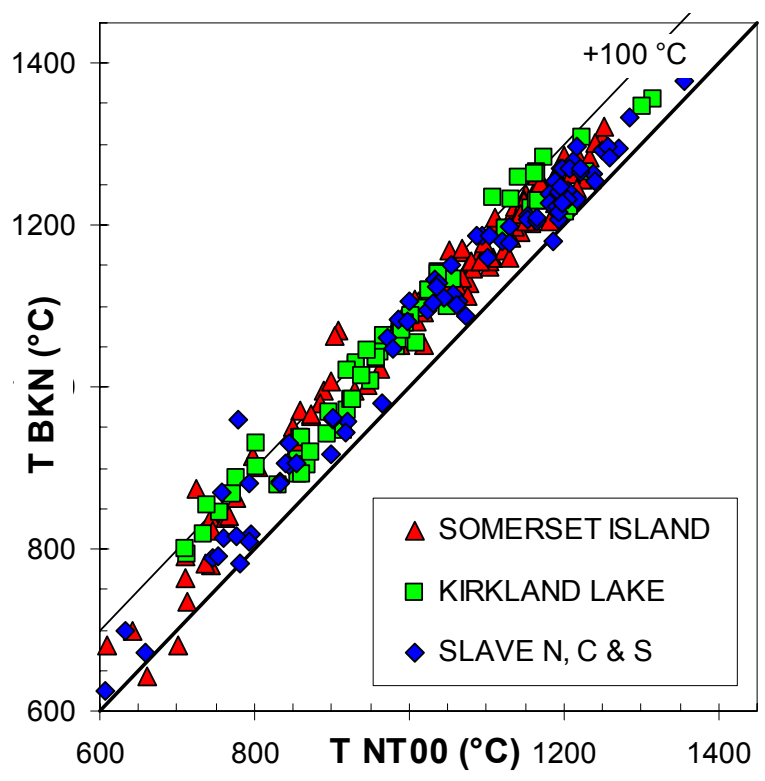

Figure 1: Cpx-solvus thermometry results for Canadian garnet peridotite xenoliths. Somerset Island data from Mitchell (1977, 1978), Jago \& Mitchell (1987), Kjarsgaard \& Peterson (1992), Zhao et al (1997) and Schmidberger \& Francis (1999). Kirkland Lake data from Meyer et al (1994) and Vicker (1997). Slave craton North, Central and South data from Kopylova et al (1999), MacKenzie \& Canil (1999), Pearson et al (1999) and Caro (2000). 
Our thermobarometry results were inspected for internal consistency and gross disequilibrium bearing in mind the comments made by Smith and Barron (1991) and Smith (1999) regarding pyroxene (re)equilibration. Relatively few data were discarded, but our lowtemperature results require further scrutinity.

\section{INITIAL RESULTS AND DISCUSSION}

\section{CANADIAN LOCALITIES}

P-T results for garnet-bearing lherzolite and pyroxenite xenoliths from the Somerset Island, Kirkland Lake and Slave craton kimberlites are shown in Figure 2. Geothermal arrays for these localities are well defined because they span the range 700 to $\sim 1350^{\circ} \mathrm{C}$ with few apparent discontinuities. Significant thermal resetting of high-pressure peridotite is however characteristic of xenoliths from the Jericho and Diavik localities in the Slave craton (Fig. 2). The P-T data suggest that pyroxene compositions were at, or close to, equilibrium since systematically different relative geothermal arrays are defined for different kimberlite provinces using either of the four thermobarometer combinations. Geothermal arrays defined by Opx-Grt barometry follow models for equilibrated conductive lithosphere (like those of Pollack and Chapman, 1977) because the $\mathrm{T}$ dependence of the PMC74, PBKN and PNG85 barometers is of the order of $40-60 \mathrm{bar} /{ }^{\circ} \mathrm{C}$. The $\mathrm{Cpx}-\mathrm{Grt}$ barometer of Nimis and Taylor (2000) has a lesser $\mathrm{T}$ dependence, of the order $25-50 \mathrm{bar} /{ }^{\circ} \mathrm{C}$, resulting in geothermal arrays that transect thermal models for conductive lithosphere at a shallow angle (Fig. 2). This fundamental difference in pyroxene thermobarometry result is most obvious for the Somerset Island data: PNT00 results for Cpx-Grt fall effectively parallel to the graphite-diamond equilibrium at $\mathrm{T}>850^{\circ} \mathrm{C}$, but PMC74, PBKN or PNG85 calculations using Opx-Grt data from the same xenoliths show a clear intersection with the diamond stability field (Fig. 2).

Absolute geotherms vary as a function of thermobarometer employed, as seen by the proximity of geothermal arrays to the graphite / diamond equilibrium (Fig. 2). In our calculations absolute $P$ differences result only from the barometer employed because we used a fixed value of TNT00 for each xenolith (see Data Sources and Methods). Typical differences in calculated $\mathrm{P}$ are illustrated in Figure 3. Opx-Grt barometers tend to yield $\mathrm{P}<\mathrm{PNT00}$ at low pressure and P $>$ PNT00 at high pressure, with absolute differences

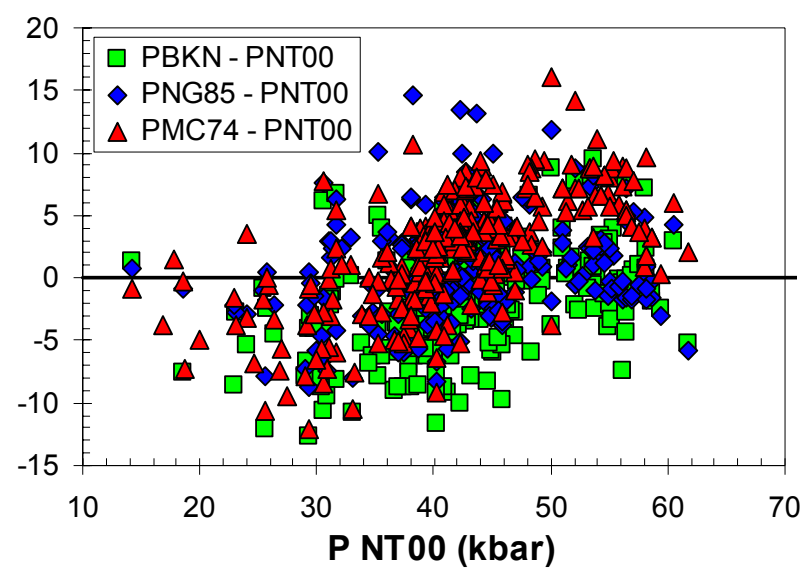

Figure 3: $\mathrm{P}$ difference between Opx-Grt barometry and Cpx-Grt barometry for Canadian garnet peridotite xenoliths. All pressures calculated at TNT00.

approaching $\pm 10 \mathrm{kbar}$ in several instances. While the $\mathrm{P}-\mathrm{T}$ trends in our results point to acceptable relative precision (Figs. 2 and 3), the absolute accuracy of any specific P-T combination requires testing against an independent constraint. The occurrence of graphite or diamond in xenoliths may, in principle, be used for this purpose and we will pursue this further during our ongoing investigation.

An alternative approach may be to empirically "anchor" geotherms relative to one another using the results from the Canadian xenolith localities (Fig. 2), and to compare the trends obtained with other wellknown xenolith localities, like those from Southern Africa. This relative thermobarometry approach has the advantages that it facilitates rapid identification of inconsistent or disequilibrium data and that it is immune to the calibration problems illustrated in Fig. 2. The empirical approach may also compensate for P-T covariance problems that occur with conventional pyroxene thermobarometry calculations.

\section{SOUTHERN AFRICAN LOCALITIES}

P-T results for garnet-bearing lherzolite and pyroxenite xenoliths from the Gibeon, North Lesotho and Kimberley Mines kimberlites are shown in Figure 4. Geothermal arrays for these localities show comparatively little relative variation and are almost coincident at $\mathrm{T}<1050^{\circ} \mathrm{C}$. With the notable exception of higher $\mathrm{P}$ estimates given by the PMC74 barometer, it is apparent that absolute pressure differences between Opx-Grt and Cpx-Grt barometers are less pronounced than observed for the Canadian xenoliths (compare Figs 2 and 4). However, the P-T scatter produced by the Cpx-Grt thermobarometer appears to be higher than 

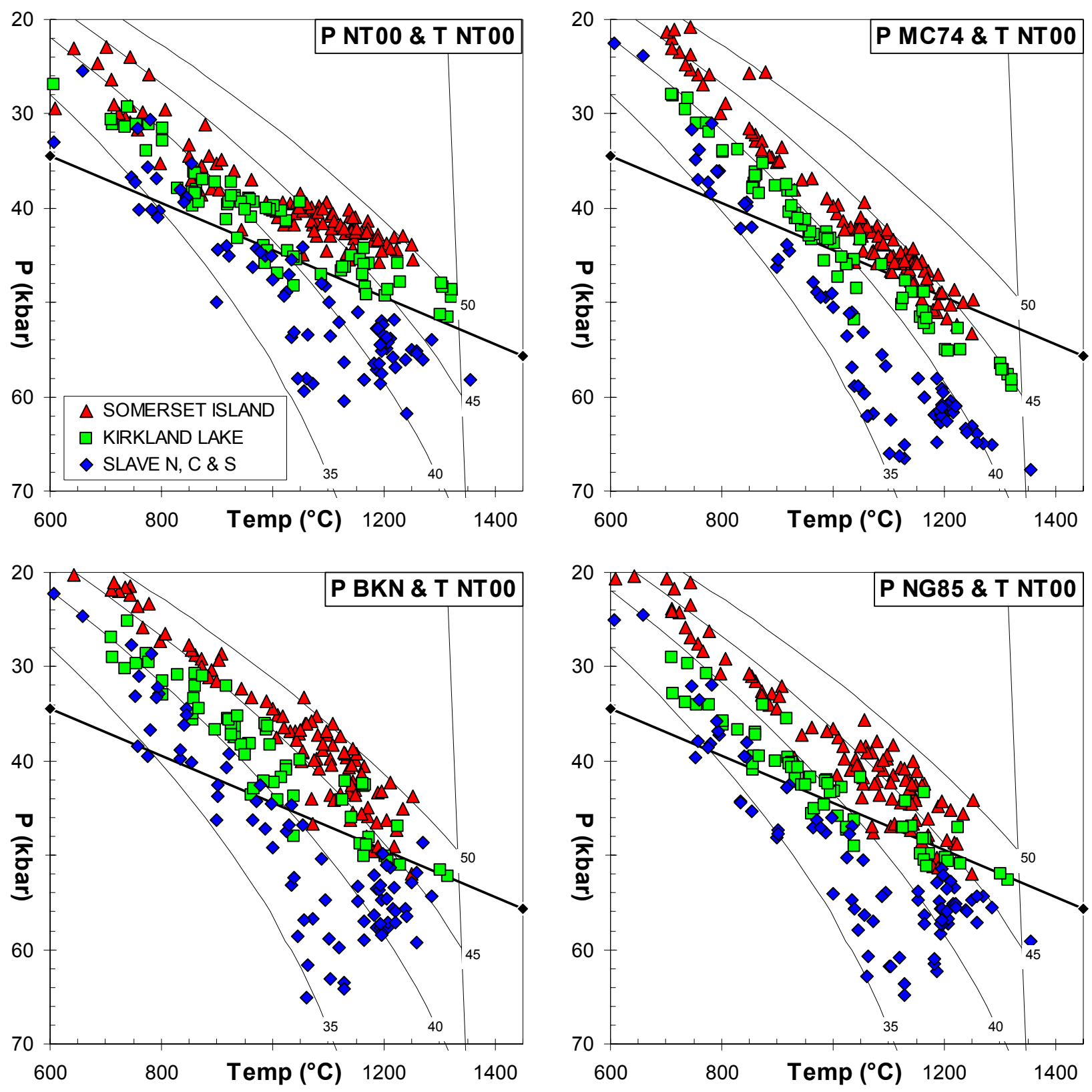

Figure 2: P-T results for peridotite xenoliths from Canadian kimberlite provinces. Model conductive geotherms labeled 35, 40, 45 and 50 are after Pollack and Chapman (1977) and terminate at high temperature in a mantle adiabat with $\mathrm{T}_{\mathrm{p}}=1300^{\circ} \mathrm{C}$. The graphite/diamond equilibrium is that of Kennedy and Kennedy (1976). Localities represented are JP, Ham, Elwin Bay, Amayersuk, Nanorluk, Batty Bay and Nikos (Somerset Island kimberlites), C14, A1, A4 and B30 (Kirkland Lake kimberlites) and Jericho, Torrie, Diavik and 5034 (Slave craton kimberlites).

that of Opx-Grt thermobarometry, in particular for the North Lesotho data (Fig. 4). This may indicate that several clinopyroxene grains occurring in North Lesotho garnet peridotites are not necessarily in equilibrium with orthopyroxene, or that they have

suffered some form of $\mathrm{Cr}-\mathrm{Al}-\mathrm{Fe}^{3+}-\mathrm{Na}$ disturbance during depressurisation of the xenoliths. These observations require further investigation. Hightemperature thermal resetting is not evident in the Kimberley data set, but is characteristic of the Gibeon province data at $\mathrm{T}>1120^{\circ} \mathrm{C}$, and at $\mathrm{T}>1200^{\circ} \mathrm{C}$ in the case of Northern Lesotho. Some of the North Lesotho xenoliths consistently show temperatures in excess of the $1300^{\circ} \mathrm{C}$ adiabat, possibly implicating an additional heat source like a mantle plume in the genesis of the North Lesotho kimberlites. 

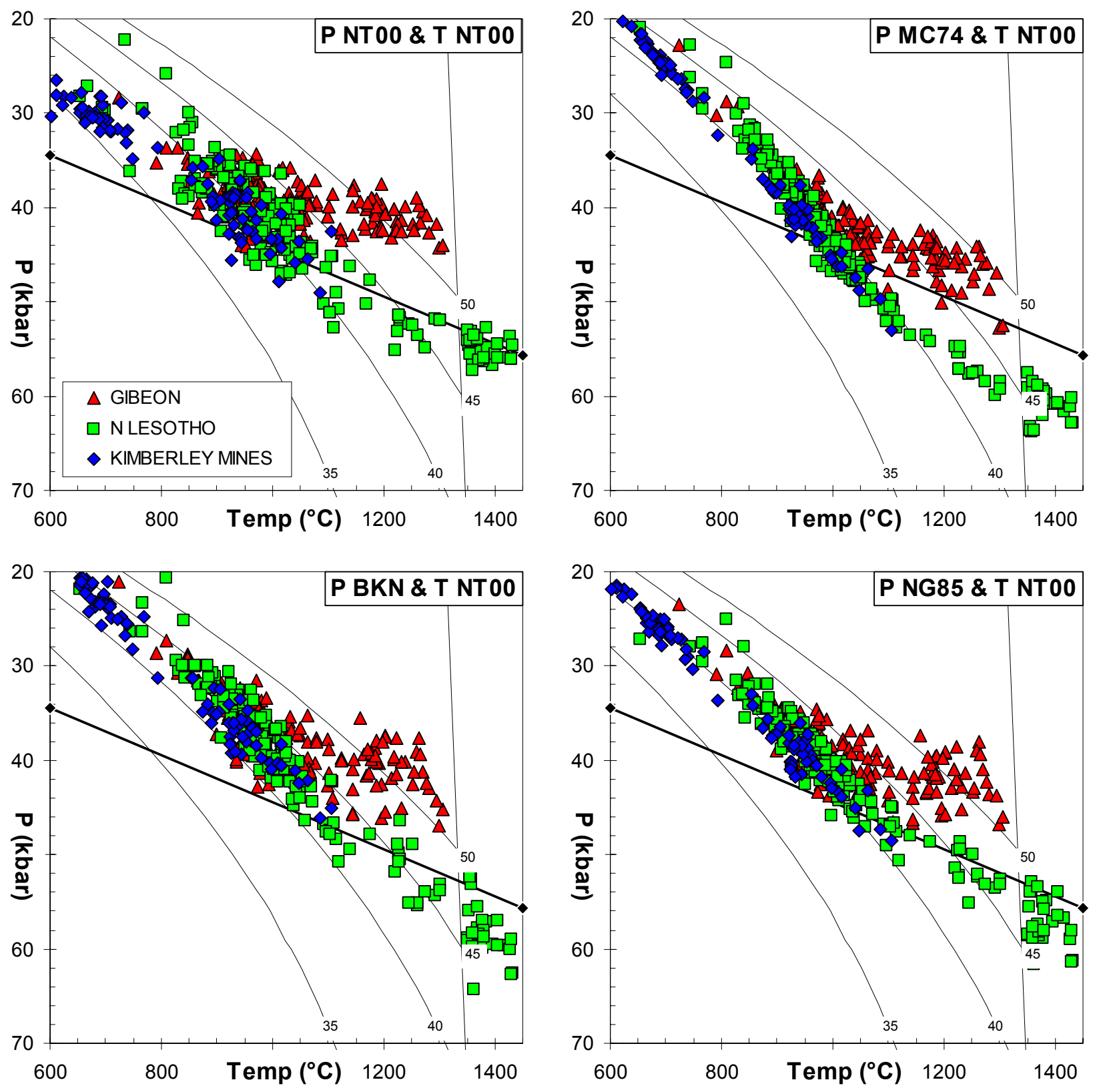

Figure 4: P-T results for peridotite xenoliths from Southern African kimberlite provinces. Localities represented are Anis Kubub, Gibeon Townlands, Hanaus and Louwrencia (Gibeon kimberlites), De Beers, Bultfontein, Wesselton and Bultfontein Floors (Kimberley Mines) and Letseng la Terae, Thaba Putsoa, Mothae, Matsoku, Kao, Liqhobong, Sekameng, Lemphane and Pipe 200 (Northern Lesotho).

\section{CONCLUSION: QUO VADIS?}

A comparison of Figs. 2 and 4 shows that the Canadian xenolith localities record geothermal variations over a continuous temperature interval and across a wider

relative range than the classic Southern African localities previously used by authors like Boyd (1973) or Mercier (1980) to illustrate the virtues of pyroxene thermobarometry. It follows that the empirical pyroxene thermobarometry approach outlined by our initial work should concentrate on Canadian xenolith localities and seek to include additional data from localities with "oceanic" geotherms (like Malaita, Vitim or Pali-Aike). 


\section{REFERENCES}

Brey, G., Köhler T., Nickel, K.G. (1990) Geothermobarometry in four-phase lherzolites I. Experimental results from 10 to $60 \mathrm{~kb}$. J. Petrol. 31, 1313-1352.

Boyd, F.R., 1973. A pyroxene geotherm. Geochim. Cosmochim. Acta 37, 2533-2546.

Boyd, F.R., England, J.L., 1964. The system enstatite-pyrope. Carnegie Inst. Washington Yearbook 63, 157-161.

Carswell, D.A., 1991. The garnet-orthopyroxene Al barometer: problematic application to natural garnet lherzolite assemblages. Mineral. Mag. 55, 19-31.

Finnerty, A.A., Boyd, F.R., 1987. Thermobarometry for garnet peridotites: basis for the determination of thermal and compositional structure of the upper mantle. In: Nixon, P.H. (Ed.) Mantle Xenoliths. Wiley \& Sons, pp. 381-402.

Kennedy, C.S., Kennedy, G.C., 1976. The equilibrium boundary between graphite and diamond. J. Geophys. Res. 81, 2467-2470.

MacGregor, I.D., 1974. The system MgO-Al2O3-SiO2 : Solubility of $\mathrm{A} 12 \mathrm{O} 3$ in enstatite for spinel and garnet peridotite compositions. Am. Mineral. 59, 110-119.

Mercier, J-C. C., 1980. Single-pyroxene thermobaro-metry. Tectonophys. 70, 1-37.

Nickel, K.G., 1989. Garnet-pyroxene equilibria in the system $\mathrm{SiO}_{2}-\mathrm{MgO}-\mathrm{Al}_{2} \mathrm{O}_{3}-\mathrm{CaO}-\mathrm{Cr}_{2} \mathrm{O}_{3}$ (SMACCR): the $\mathrm{Cr}-$ geobarometer. Proc. $4^{\text {th }}$ Int. Kimberlite Conf. Geol. Soc. Austral. Spec. Publ. 14, 901-912.

Nickel, K.G., Green, D.H., 1985. Empirical geothermobarometry for garnet peridotites and implications for the nature of the lithosphere, kimberlites and diamonds. Earth Planet. Sci. Lett. 73, 158-170.

Nimis P. and Taylor W. R., 2000. Single clinopyroxene thermobarometry for garnet peridotites. Part 1 . Calibration and testing of a Cr-in-Cpx barometer and an enstatite-in-Cpx thermometer. Contrib. Mineral. Petrol. 139, 541-554.

Pollack, H.N., Chapman, D.S., 1977. On the regional variation of heat flow, geotherms, and lithospheric thickness. Tectonophysics 38, 279-296.

Smith D. and Barron B. R., 1991. Pyroxene-garnet equilibration during cooling in the mantle. Am. Mineral. 76, 1950-1963.

Smith, D., 1999. Temperatures and pressures of mineral equilibration in peridotite xenoliths: Review, discussion, and implications. In: Fei, Y., Bertka, C.M., Mysen, B.O. (Eds.) Mantle Petrology: Field observations and high pressure experimentation: A tribute to Francis R. (Joe) Boyd. Spec. Publ. Geochemical Soc. 6, 171-188.

Taylor, W.R. (1998) An experimental test of some geothermometer and geobarometer formulations for upper mantle peridotites with application to the thermobarometry of fertile lherzolite and garnet websterite. N. Jahrb. Mineral. Abh. 172, 381-408.

\section{APPENDIX 1: REFERENCES FOR XENOLITH DATA}

Caro, G., 2000. Petrography of the Kennedy Lake orangeite and its mantle xenoliths. Unpubl. M. Sc. Thesis, Univ. British Columbia, 100 pp.

Jago, B.C., Mitchell, R.H., 1987. Ultrabasic xenoliths from the Ham kimberlite, Somerset Island, Northwest Territories. Canadian Mineralogist 25, 515-525.

Kjarsgaard, B.A., Peterson, T.D., 1992. Kimberlite-derived ultramafic xenoliths from the diamond stability field: a new Cretaceous geotherm for Somerset Island, Northwest Territories. In: Current Research, Part B, Geol. Surv. Canada Paper 92-1B, 1-6.

Kopylova, M.G., Russel, J.K., Cookenboo, H., 1999. Petrology of peridotite and pyroxenite xenoliths from the Jericho kimberlite: Implications for the thermal state of the mantle beneath the Slave craton, Northern Canada. . J. Petrol. 40, 79-104.

MacKenzie, J.M., Canil, D., 1999. Composition and thermal evolution of cratonic mantle beneath the central Archean Slave province, NWT, Canada. Contrib. Mineral. Petrol. 134, 313-324.

Meyer, H.O., Waldman, M.A., Garwood, B.L., 1994. Mantle xenoliths from kimberlite near Kirkland Lake, Ontario. Canadian Mineral. 32, 295-306.

Mitchell, R.H., 1977. Ultramafic xenoliths from the Elwin Bay kimberlite: the first Canadian paleogeotherm. Can. J. Earth Sci. 14, 1202-1210.

Mitchell, R.H., 1978. Garnet lherzolites from Somerset Island, Canada and aspects of the nature of perturbed geotherms. Contrib. Mineral. Petrol. 67, 341-347.

Pearson, N.J., Griffin, W.L., Doyle, B.J., O'Reilly, S.Y., van Achterbergh. E., Kivi, K., 1999. Xenoliths from kimberlite pipes of the Lac de Gras area, Slave craton, Canada. In: Gurney, J.J., Gurney, J.L., Pascoe, M.D., Richardson, S.H., (Eds.), P. H. Nixon volume, Proceedings of the 7 th International Kimberlite Conference, Red Roof Design, Cape Town, 644-658.

Schmidberger, S.S., Francis, D., 1999. Nature of mantle roots beneath the North American craton: mantle xenolith evidence from Somerset Island kimberlites. Lithos 48, 195-216.

Vicker, P.A., 1997. Garnet peridotite xenoliths from kimberlite near Kirkland Lake, Canada. Unpubl. MSc. Thesis, Univ. of Toronto, $127 \mathrm{pp}$.

Zhao. D., Essene. E.J., Zhang. Y., Hall. C.M., Wang, L. 1997. EGS 1997-5 Newly discovered kimberlites and mantle xenoliths from Somerset Island and Broduer Peninsula, Canada: Pressure, Temperature, Oxygen Fugacity, Volatile Content and Age. NWT Geol. Division, Yellowknife, NWT, 105 pp.

Contact: H. S. Grutter, Mineral Services Canada, \#1300 - 409 Granville Street, Vancouver, B.C., V6N 1T2, Canada. Email: herman.grutter@mineralservices.com 